\title{
Nutrient intake, acid base status and weight gain in water buffalo calves fed different dietary levels of sodium bicarbonate
}

\author{
M. Sarwar", M.A. Shahzad, M. Nisa \& S. Amjad \\ Institute of Animal Nutrition and Feed Technology, University of Agriculture, Faisalabad, Pakistan
}

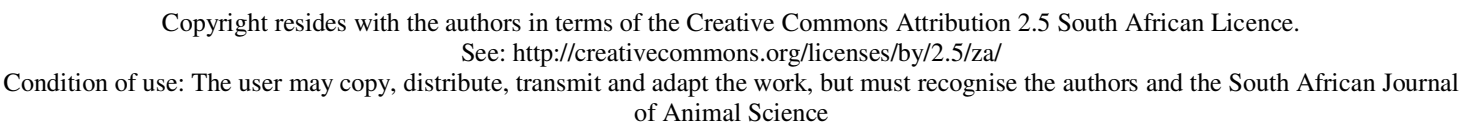

Copyright resides with the authors in terms of the Creative Commons Attribution 2.5 South African Licence. See: http://creativecommons.org/licenses/by/2.5/za/

Condition of use: The user may copy, distribute, transmit and adapt the work, but must recognise the authors and the South African Journal of Animal Science

\begin{abstract}
The impact of different dietary levels of sodium bicarbonate $\left(\mathrm{NaHCO}_{3}\right)$ on nutrient intake, acid-base status, nitrogen balance and weight gain was examined in growing male buffalo (Bubalus bubalis) calves exposed to hot summer conditions. In a complete randomized block design 60 animals of similar age and weight were divided into five treatment groups of 12 per group. Five isonitrogenous and isoenergetic diets were formulated and randomly allocated to a treatment group. The control diet (0SB) contained no $\mathrm{NaHCO}_{3}$, while diets $4 \mathrm{SB}, 8 \mathrm{SB}, 12 \mathrm{SB}$ and $16 \mathrm{SB}$ contained $0.4,0.8,1.2$ and $1.6 \% \mathrm{NaHCO}_{3}$, respectively. An increase in nutrient intake was recorded with increasing dietary $\mathrm{NaHCO}_{3}$ level while the reverse was true for nutrient digestibility. Calves fed the 12SB and 16SB diets had higher nitrogen retentions than those fed the 0SB and 4SB diets. Significant increases in blood $\mathrm{pH}$, serum $\mathrm{HCO}_{3}$ and urine $\mathrm{pH}$ were recorded with increasing $\mathrm{NaHCO}_{3}$ levels, with the highest in calves receiving the 16SB diet. Calves fed the 14SB and 16SB diets gained more weight than those fed the 0SB and 4SB diets. These results indicate that the best nutrient intake, acid-base status, nitrogen retention and weight gain occurred in the calves receiving the diet containing $1.2 \%$ $\mathrm{NaHCO}_{3}$.
\end{abstract}

Keywords: Bubalus bubalis, buffer, ruminal $\mathrm{pH}$, acidosis, weight gain

${ }^{\#}$ Corresponding author: drms01@ gmail.com

\section{Introduction}

A consistent supply of macro and micro nutrients to growing water buffalo (Bubalus bubalis) calves is important to attain high growth rates, and would contribute to a profitable income (Sarwar et al., 2002a; Shahzad et al., 2009a; b). This can be achieved by ensuring ingestion of sufficient nutrients and energy, thus ensuring the efficient utilization of nutrients for weight gain (Mandebvu \& Galbraith, 1999). However, feeding diets containing high levels of concentrates reduce ruminal $\mathrm{pH}$ (Javaid et al., 2008). Rumen $\mathrm{pH}$ represents the balance between the acids generated from the fermentation of feeds and the bicarbonate and phosphate buffers in saliva which neutralize these acids. Increased proportions of readily fermentable nutrients in the diet reduce the proportion of effective fibre in the diet, which is essential for copious saliva production through stimulated chewing activity, and consequently effective rumen buffering. Saliva flow rates in mature ruminants are estimated to be in the range of 108 to 308 litres per day which can supply from 1134 to $3234 \mathrm{~g}$ sodium bicarbonate $\left(\mathrm{NaHCO}_{3}\right)$ per day for the buffering of the rumen content (Erdman, 1988). A reduced effective fibre concentration in the diet reduces salivary activities thus preventing the required supply of salivary $\mathrm{NaHCO}_{3}$ to counteract acidity produced by rumen fermentation. This chain of events reduces rumen buffering capacity and favours the accumulation of volatile fatty acids and lactic acid in the rumen that ultimately leads to ruminal acidosis (Owens et al., 1998).

Metabolic or systemic acidosis is aggravated in the hot summer because rapid respiration by calves to dissipate heat reduces carbonic acid concentration in the blood leading to respiratory alkalosis, which, because of excessive loss of $\mathrm{HCO}_{3}$ in urine, reduces the buffering capacity in blood. The net effect is a reduction in intake of energy and nutrients, and a reduced growth rate.

Several nutritional therapies have been suggested, with variable success, to maintain the buffering capacity in the rumen and blood of ruminants consuming high concentrate diets. Among these, the addition

URL: http://www.sasas.co.za

ISSN 0375-1589 (print), ISSN 222-4062 (online)

Publisher: South African Society for Animal Science 
of buffers such as sodium bicarbonate $\left(\mathrm{NaHCO}_{3}\right)$ does not only prevent the reduction in ruminal $\mathrm{pH}(\mathrm{Owens}$ et al., 1998) but also improves blood buffering capacity (Sarwar et al., 2007a; Shahzad et al., 2007). The favourable effects of $\mathrm{NaHCO}_{3}$ supplementation in intensive ruminant farming systems are well documented in the literature (Belibasakis \& Triantosa, 1991; West et al., 1991; Sanchez et al., 1997). However, the direct application of these results, mostly obtained in temperate zones to water buffalo calves reared under hot and humid environmental conditions appears to be inappropriate. Furthermore, water buffalo calves lack sweat glands and, being black in colour, can absorb twice the amount of radiation during the hot summer than white animals. Limited scientific information is available on the effect of including $\mathrm{NaHCO}_{3}$ in concentrate diets fed to male buffalo calves in hot summer conditions. Therefore, the present experiment was designed to determine the effect of different levels of $\mathrm{NaHCO}_{3}$ on dry matter intake (DMI), crude protein (CP), neutral detergent fibre (NDF) and acid detergent fibre (ADF), their digestibility, nitrogen (N) balance and growth performance of growing male water buffalo calves fed a high concentrate diet.

\section{Materials and Methods}

The experiment was conducted on five commercial feedlot farms in the district, Toba Tek Singh, in Pakistan. The average day-time temperature recorded during the study period remained at $40.4 \pm 4.55{ }^{\circ} \mathrm{C}$. The study lasted for 12 weeks. The first three weeks were an adaptation period and the fourth week served as the first collection period, while every last week of the remaining two months served as collection periods, (i.e. three collection periods of one week each). Sixty growing male water buffalo calves, $10-12$ months of age, were allocated to five treatments according to a complete randomized block design. Five isoenergetic and isonitrogenous total mixed diets were formulated in which different levels of $\mathrm{NaHCO}_{3}$ were included (Table 1). The control diet (0SB) was formulated without $\mathrm{NaHCO}_{3}$, while the other four diets, 4SB, 8SB, $12 \mathrm{SB}$ and $16 \mathrm{SB}$, contained $0.4,0.8,1.2$ and $1.6 \% \mathrm{NaHCO}_{3}$, respectively. The calves were kept in individual pens. Feed was mixed daily and offered twice a day in the morning and evening at a $10 \%$ refusal level with daily recording of feed intake. The animals had free access to drinking water throughout the study.

Initial body weights of the animals were recorded prior to the start of the experiment. Thereafter body weights were recorded every 15 days. Urine collections were made fortnightly, using special leather buckets tied to the belly of the calves and fitted with plastic pipes ending in large cylindrical containers. The urine was acidified with $50 \% \mathrm{H}_{2} \mathrm{SO}_{4}$, and $20 \%$ of it was sampled and preserved at $-20{ }^{\circ} \mathrm{C}$ (Shahzad et al., 2008a). The preserved urine samples were pooled per animal after thawing and $10 \%$ was used for analysis at the end of each collection period. Similarly, faecal grab samples were collected twice daily during every collection period and digestibility determined using an internal marker, acid insoluble ash. Feed, orts and faecal samples were mixed thoroughly to obtain composite samples of each animal at the end of a collection period. These samples were dried at $55{ }^{\circ} \mathrm{C}$, bulked and analyzed for dry matter (DM), CP, ash, sodium (Na), potassium $(\mathrm{K})$, chlorine $(\mathrm{Cl})$, calcium $(\mathrm{Ca})$, phosphorus $(\mathrm{P})$, magnesium $(\mathrm{Mg})$ and sulphur $(\mathrm{S})$ (AOAC, 2003), and NDF (Van Soest et al., 1991) and ADF (Goering \& Van Soest, 1970).

During each collection period blood samples were collected twice at 6 and $12 \mathrm{~h}$ post feeding. Twelve $\mathrm{mL}$ blood were collected from the jugular vein into two different heparinized vacuum tubes. One of the tubes was placed immediately on crushed ice to determine blood $\mathrm{pH}$ within two hours (Tucker et al., 1991). Serum from the other tube was separated and used to analyze $\mathrm{Na}, \mathrm{K}, \mathrm{Cl}, \mathrm{Ca}, \mathrm{P}, \mathrm{Mg}$ and $\mathrm{S}$ concentrations via atomic absorption spectrophotometry (AOAC, 2003). Serum $\mathrm{HCO}_{3}$ concentration was determined by the method of Harold (1976). Analysis of variance (ANOVA) was used to analyze the data (SAS, 1988). Differences between treatment means were compared using the Duncan's New Multiple Range test at a 5\% probability level (Steel \& Torrie, 1984).

\section{Results}

Nutrient intake increased $(P<0.05)$ with increasing levels of dietary $\mathrm{NaHCO}_{3}$ (Table 2). Minimum $(6.23 \mathrm{~kg} / \mathrm{d})$ and maximum $(7.45 \mathrm{~kg} / \mathrm{d}) \mathrm{DM}$ intakes were recorded in calves fed the 0SB and 16SB diets, respectively. The CP consumption was highest $(1176 \mathrm{~g} / \mathrm{d})$ for calves fed the $16 \mathrm{SB}$ diet and lowest $(984 \mathrm{~g} / \mathrm{d})$ in calves fed the 0SB diet. Likewise, the NDF intake was the highest $(2638 \mathrm{~g} / \mathrm{d})$ in the 16SB treatment and lowest $(2206 \mathrm{~g} / \mathrm{d})$ for calves fed the OSB diet. A similar trend was recorded for ADF (Table 2). Dry matter digestibility decreased linearly with increasing levels of $\mathrm{NaHCO}_{3}$ in the diet (Table 2). The lowest and 
Table 1 Ingredients and chemical composition of experimental diets for growing male water buffalo calves

\begin{tabular}{|c|c|c|c|c|c|}
\hline & \multicolumn{5}{|c|}{$\operatorname{Diets}^{1}$} \\
\hline & OSB & $4 \mathrm{SB}$ & $8 \mathrm{SB}$ & $12 \mathrm{SB}$ & $16 \mathrm{SB}$ \\
\hline \multicolumn{6}{|l|}{ Ingredients (g/kg) } \\
\hline Wheat straw & 300 & 300 & 300 & 300 & 300 \\
\hline Maize grain cracked & 150 & 150 & 150 & 150 & 150 \\
\hline Rice polishing & 100 & 100 & 100 & 100 & 100 \\
\hline Sunflower meal & 80 & 80 & 80 & 80 & 80 \\
\hline Maize oil cake & 100 & 100 & 100 & 100 & 100 \\
\hline Maize gluten $30 \%$ & 180 & 180 & 180 & 180 & 180 \\
\hline Molasses & 62 & 58 & 54 & 50 & 46 \\
\hline Salt & 5 & 5 & 5 & 5 & 5 \\
\hline Urea & 10 & 10 & 10 & 10 & 10 \\
\hline Dicalcium phosphate & 13 & 13 & 13 & 13 & 13 \\
\hline $\mathrm{NaHCO}_{3}$ & 0 & 4 & 8 & 12 & 16 \\
\hline \multicolumn{6}{|l|}{ Chemical composition (g/kg) } \\
\hline $\mathrm{ME}(\mathrm{MJ} / \mathrm{kg})$ & 9.7 & 9.7 & 9.7 & 9.7 & 9.7 \\
\hline Crude protein & 158 & 158 & 158 & 158 & 158 \\
\hline Neutral detergent fibre & 354 & 354 & 354 & 354 & 354 \\
\hline Acid detergent fibre & 212 & 212 & 212 & 212 & 212 \\
\hline NFC & 199 & 199 & 199 & 199 & 199 \\
\hline Calcium & 7 & 7 & 7 & 7 & 7 \\
\hline Phosphorus & 4 & 4 & 4 & 4 & 4 \\
\hline Sodium & 3 & 4 & 5 & 6 & 8 \\
\hline Potassium & 4 & 4 & 4 & 5 & 5 \\
\hline Magnesium & 2 & 2 & 2 & 2 & 2 \\
\hline Chlorine & 2 & 2 & 2 & 2 & 2 \\
\hline Sulphur & 2 & 2 & 2 & 2 & 2 \\
\hline $\mathrm{DCAD}, \mathrm{mEq} / \mathrm{kg}$ & 30.3 & 80.1 & 120.9 & 190.8 & 260.4 \\
\hline
\end{tabular}

highest DM digestibility $(P<0.05)$ were recorded for calves fed the OSB and 16SB diets, respectively. Crude protein digestibility followed a similar trend. The NDF and ADF digestibilities also decreased with increasing $\mathrm{NaHCO}_{3}$ levels.

Nitrogen intake increased with increasing $\mathrm{NaHCO}_{3}$ level (Table 2). Consequently, $\mathrm{N}$ intake was the highest $(188.1 \mathrm{~g} / \mathrm{d})$ in the calves on the $16 \mathrm{SB}$ diet and lowest $(157.5 \mathrm{~g} / \mathrm{d})$ on the 0SB diet. Despite that, calves fed the 16SB diet retained more $(P<0.05) \mathrm{N}$ than those on the other diets, resulting in the highest $\mathrm{N}$ balance in calves on the 16SB diets and the lowest in calves on the control (0SB) diet (Table 3).

Blood $\mathrm{pH}$ was the lowest $(7.26, P<0.05)$ in calves fed the 0SB diet and highest $(7.57, P<0.05)$ in those fed the 16SB diet (Table 4). A consistent increase $(P<0.05)$ in blood $\mathrm{HCO}_{3}$ concentration was recorded with increasing $\mathrm{NaHCO}_{3}$ level in the diet (Table 4). The highest $(28.3 \mathrm{mmol} / \mathrm{L})$ and lowest $(24.1$ mmol/L) serum $\mathrm{HCO}_{3}$ concentrations $(P<0.05)$ were recorded in calves fed the 16SB and 0SB diets, respectively. A linear increase in urine $\mathrm{pH}(P<0.05)$ was observed with increasing levels of $\mathrm{NaHCO}_{3}$ in the 
Table 2 Effect of increasing levels of sodium bicarbonate on nutrient intake and their digestibility in growing male water buffalo calves

\begin{tabular}{lcccccc}
\hline & \multicolumn{5}{c}{ Diets $^{1}$} & \multirow{2}{*}{ SEM } \\
\cline { 2 - 5 } & OSB & 4SB & 8 SB & 12 SB & 16 SB & \\
\hline Nutrient intake (g/d) & $6.23^{\mathrm{c}}$ & $6.38^{\mathrm{bc}}$ & $6.75^{\mathrm{b}}$ & $7.16^{\mathrm{ab}}$ & $7.45^{\mathrm{a}}$ & 0.39 \\
Dry matter (kg/d) & $984^{\mathrm{c}}$ & $1008^{\mathrm{bc}}$ & $1065^{\mathrm{b}}$ & $1130^{\mathrm{ab}}$ & $1176^{\mathrm{a}}$ & 98.75 \\
Crude protein & $2206^{\mathrm{c}}$ & $2259^{\mathrm{bc}}$ & $2390^{\mathrm{b}}$ & $2535^{\mathrm{ab}}$ & $2638^{\mathrm{a}}$ & 220.5 \\
Neutral-detergent fibre & $1323^{\mathrm{c}}$ & $1355^{\mathrm{c}}$ & $1433^{\mathrm{b}}$ & $1520^{\mathrm{ab}}$ & $1582^{\mathrm{a}}$ & 145.4 \\
Acid-detergent fibre & $0.712^{\mathrm{a}}$ & $0.690^{\mathrm{ab}}$ & $0.682^{\mathrm{b}}$ & $0.681^{\mathrm{bc}}$ & $0.681^{\mathrm{c}}$ & 0.0008 \\
Nutrient digestibility (expressed as coefficients) & $0.731^{\mathrm{a}}$ & $0.720^{\mathrm{ab}}$ & $0.711^{\mathrm{b}}$ & $0.711^{\mathrm{bc}}$ & $0.709^{\mathrm{c}}$ & 0.0004 \\
Dry matter & $0.654^{\mathrm{a}}$ & $0.642^{\mathrm{ab}}$ & $0.642^{\mathrm{b}}$ & $0.641^{\mathrm{bc}}$ & $0.634^{\mathrm{c}}$ & 0.0090 \\
Crude protein & $0.633^{\mathrm{a}}$ & $0.623^{\mathrm{ab}}$ & $0.622^{\mathrm{b}}$ & $0.620^{\mathrm{bc}}$ & $0.618^{\mathrm{c}}$ & 0.0072 \\
Neutral-detergent fibre & & & & &
\end{tabular}

${ }_{\text {a,b,c }}$ Means within the same row having different superscripts differ significantly $(P<0.05)$.

${ }^{1}$ Diet 0 SB contained no sodium bicarbonate while the 4SB, 8SB, 12SB and 16SB diets contained 0.4, $0.8,1.2$ and $1.6 \%$ sodium bicarbonate, respectively.

Table 3 Effect of increasing levels of sodium bicarbonate on nitrogen balance in growing male water buffalo calves

\begin{tabular}{|c|c|c|c|c|c|c|}
\hline \multirow{2}{*}{ Nitrogen metabolism } & \multicolumn{5}{|c|}{ Diets $^{1}$} & \multirow{2}{*}{ SEM } \\
\hline & OSB & $4 \mathrm{SB}$ & $8 \mathrm{SB}$ & $12 \mathrm{SB}$ & $16 S B$ & \\
\hline Intake & $157.5^{\mathrm{c}}$ & $161.3^{\mathrm{bc}}$ & $170.4^{\mathrm{b}}$ & $180.8^{\mathrm{ab}}$ & $188.1^{\mathrm{a}}$ & 21.41 \\
\hline Faecal excretion & $41.2^{\mathrm{c}}$ & $44.1^{\mathrm{bc}}$ & $46.9^{\mathrm{b}}$ & $51.6^{\mathrm{ab}}$ & $52.2^{\mathrm{a}}$ & 3.95 \\
\hline$\%$ of intake & 26.2 & 27.4 & 27.5 & 28.5 & 27.8 & 0.37 \\
\hline Apparent absorption & $116.3^{\mathrm{a}}$ & $177.2^{\mathrm{c}}$ & $123.5^{\mathrm{b}}$ & $129.2^{\mathrm{ab}}$ & $135.9^{\mathrm{a}}$ & 11.52 \\
\hline$\%$ of intake & 73.8 & 72.7 & 72.5 & 71.5 & 72.2 & 1.78 \\
\hline Urinary excretion & $10.22^{\mathrm{c}}$ & $11.4^{\mathrm{bc}}$ & $11.4^{\mathrm{b}}$ & $11.8^{\mathrm{ab}}$ & $11.9^{\mathrm{a}}$ & 1.97 \\
\hline$\%$ of intake & 6.49 & 7.06 & 6.71 & 6.50 & 6.32 & 0.45 \\
\hline Apparent retention & $106.1^{\mathrm{c}}$ & $105.8^{\mathrm{bc}}$ & $112.1^{\mathrm{b}}$ & $117.5^{\mathrm{ab}}$ & $124.0^{\mathrm{a}}$ & 4.11 \\
\hline$\%$ of intake & 67.34 & 65.6 & 65.8 & 65.0 & 65.9 & 1.01 \\
\hline Balance & $51.4^{\mathrm{c}}$ & $55.5^{\mathrm{bc}}$ & $58.3^{\mathrm{b}}$ & $63.3^{\mathrm{ab}}$ & $64.1^{\mathrm{a}}$ & 12.31 \\
\hline
\end{tabular}

diet (Table 4). The lowest (7.33) and highest $(8.02)$ urine $\mathrm{pH}$ readings $(P<0.05)$ were recorded in calves fed the $0 \mathrm{SB}$ and 16SB treatment diets, respectively. The urine $\mathrm{pH}$ 's of calves fed the 8SB and 12SB diets were 7.60 and 7.81 , respectively.

Serum $\mathrm{Na}$ concentration increased $(P<0.05)$ with increasing levels of $\mathrm{NaHCO}_{3}$ in the diet while $\mathrm{K}, \mathrm{Cl}$, $\mathrm{S}$ and $\mathrm{Mg}$ concentrations remained unaltered (Table 5). Serum Ca increased with decreasing $\mathrm{NaHCO}_{3}$ levels in the diet. In the case of serum $\mathrm{Mg}$, a slight decrease was noticed with increasing $\mathrm{NaHCO}_{3}$ levels. Serum DCAD increased with an increased level of $\mathrm{NaHCO}_{3}$ in the diet.

An increasing weight gain $(P<0.05)$ of the buffalo calves was observed with increasing $\mathrm{NaHCO}_{3}$ levels in the diet (Table 6), though FCR between treatments did not differ significantly. Calves fed the OSB 
showed the lowest $(625 \mathrm{~g} / \mathrm{d})$ weight gains and those fed the 16SB diet, the highest $(735 \mathrm{~g} / \mathrm{d})(P<0.05)$. Calves fed the $8 \mathrm{SB}$ and $12 \mathrm{SB}$ diets gained 678 and $708 \mathrm{~g} /$ day, respectively.

Table 4 Effect of increasing levels of sodium bicarbonate on blood $\mathrm{pH}$, urine $\mathrm{pH}$ and serum bicarbonate concentration in growing male water buffalo calves

\begin{tabular}{lcccccc}
\hline \multirow{2}{*}{ Variables } & \multicolumn{5}{c}{ Diets $^{1}$} & SEM \\
\cline { 2 - 5 } & OSB & 4 SB & $8 S B$ & $12 S B$ & $16 S B$ & 0.06 \\
\hline Blood $\mathrm{pH}$ & $7.26^{\mathrm{c}}$ & $7.32^{\mathrm{bc}}$ & $7.38^{\mathrm{b}}$ & $7.43^{\mathrm{ab}}$ & $7.47^{\mathrm{a}}$ & 0.28 \\
Urine $\mathrm{pH}$ & $7.33^{\mathrm{c}}$ & $7.56^{\mathrm{bc}}$ & $7.67^{\mathrm{b}}$ & $7.81^{\mathrm{ab}}$ & $8.02^{\mathrm{a}}$ & 1.01 \\
Serum $\mathrm{HCO}_{3}(\mathrm{mmol} / \mathrm{L})$ & $24.1^{\mathrm{c}}$ & $25.1^{\mathrm{bc}}$ & $25.5^{\mathrm{b}}$ & $27.0^{\mathrm{ab}}$ & $28.3^{\mathrm{a}}$ & \\
\hline
\end{tabular}

Means within the same row having different superscripts differ significantly $(P<0.05)$.

${ }^{1}$ Diet 0 SB contained no sodium bicarbonate while the 4SB, 8SB, 12SB and 16SB diets contained 0.4, 0.8, 1.2 and $1.6 \%$ of sodium bicarbonate, respectively.

Table 5 Effect of increasing levels of sodium bicarbonate on serum minerals in growing male water buffalo calves

\begin{tabular}{|c|c|c|c|c|c|c|}
\hline \multirow{2}{*}{ Minerals } & \multicolumn{5}{|c|}{ Diets $^{1}$} & \multirow{2}{*}{ SEM } \\
\hline & OSB & $4 \mathrm{SB}$ & $8 \mathrm{SB}$ & $12 \mathrm{SB}$ & $16 \mathrm{SB}$ & \\
\hline $\mathrm{Na}, \mathrm{mEq} / \mathrm{L}$ & $131.1^{\mathrm{c}}$ & $132.2^{\mathrm{c}}$ & $135.2^{\mathrm{b}}$ & $138.4^{\mathrm{ab}}$ & $141.3^{\mathrm{a}}$ & 1.89 \\
\hline $\mathrm{K}, \mathrm{mEq} / \mathrm{L}$ & 4.71 & 4.91 & 5.10 & 5.32 & 5.45 & 0.18 \\
\hline $\mathrm{Cl}, \mathrm{mEq} / \mathrm{L}$ & 91.8 & 90.1 & 89.9 & 89.7 & 89.4 & 0.08 \\
\hline $\mathrm{S}, \mathrm{mEq} / \mathrm{L}$ & $1.45^{\mathrm{c}}$ & $1.44^{\mathrm{c}}$ & $1.45^{\mathrm{b}}$ & $1.45^{\mathrm{ab}}$ & $1.43^{\mathrm{a}}$ & 0.07 \\
\hline $\begin{array}{c}\text { Serum }(\mathrm{Na}+\mathrm{K})-(\mathrm{Cl}+\mathrm{S}), \\
\mathrm{mEq} / \mathrm{L}\end{array}$ & 42.6 & 45.6 & 49.0 & 52.6 & 55.9 & 3.12 \\
\hline $\mathrm{Ca}, \mathrm{mg} / \mathrm{dL}$ & $9.39^{\mathrm{a}}$ & $9.32^{\mathrm{a}}$ & $9.26^{\mathrm{b}}$ & $9.16^{\mathrm{bc}}$ & $9.07^{\mathrm{c}}$ & 0.01 \\
\hline $\mathrm{Mg}, \mathrm{mg} / \mathrm{dL}$ & 2.41 & 2.38 & 2.36 & 2.32 & 2.27 & 0.02 \\
\hline $\mathrm{P}, \mathrm{mg} / \mathrm{dl}$ & 6.98 & 7.01 & 7.12 & 7.12 & 7.13 & 0.02 \\
\hline
\end{tabular}

Means within the same row having different superscripts differ significantly $(P<0.05)$.

${ }^{1}$ Diet 0 SB contained no sodium bicarbonate while the 4SB, 8SB, 12SB and 16SB diets contained $0.4,0.8$, 1.2 and $1.6 \%$ sodium bicarbonate, respectively.

\section{Discussion}

During hot climatic conditions, rapidly growing buffalo calves usually experience a severe problem of heat dissipation, generally referred to as heat stress. It disrupts homeostasis by evoking thermo-regulatory responses to maintain heat balance that lead to decreased feed consumption and growth (Sarwar et al., 2007b; Shahzad et al., 2007). Feeding high levels of $\mathrm{NaHCO}_{3}$ can influence the acid-base status of animals that plays a key role in body physiology (Sarwar et al., 2007a; b). Certain changes in blood chemistry can occur when high dietary $\mathrm{NaHCO}_{3}$ concentrations are fed; for example, if dietary concentration of $\mathrm{NaHCO}_{3}$ increases, it may lead to a decrease in blood $\mathrm{H}^{+}$and an increase in blood $\mathrm{HCO}_{3}^{-}$, blood $\mathrm{pH}$ and urine $\mathrm{pH}$ (Spanghero, 2004). Alteration in blood $\mathrm{pH}$ has been associated with many vital physiological functions of the body such as insulin secretion and its effectiveness may be affected (Robertson, 1987) as well as that of the growth hormone (Challa et al., 1993), dry matter intake and growth in growing animals (Jackson \& Hemken, 1994). 
Table 6 Effect of increasing levels of sodium bicarbonate on growth performance of growing male water buffalo calves

\begin{tabular}{lccccccc}
\hline \multirow{2}{*}{ Variables } & \multicolumn{9}{c}{ Diets $^{1}$} & \multirow{2}{*}{ SEM } \\
\cline { 2 - 6 } & 0SB & 4 SB & 8 SB & 12 SB & 16 SB & \\
\hline \multirow{2}{*}{ Weight gain, g/d } & $625^{\mathrm{c}}$ & $645^{\mathrm{bc}}$ & $678^{\mathrm{b}}$ & $708^{\mathrm{ab}}$ & $738^{\mathrm{a}}$ & 18.91 \\
FCR $^{2}$ & 9.98 & 9.89 & 9.96 & 10.11 & 10.14 & 0.58 \\
\hline
\end{tabular}

Means within the same row having different superscripts differ significantly $(P<0.05)$.

${ }^{1}$ Diet $0 \mathrm{SB}$ contained no sodium bicarbonate while the 4SB, 8SB, 12SB and $16 \mathrm{SB}$ diets contained $0.4,0.8,1.2$

and $1.6 \%$ of sodium bicarbonate, respectively.

${ }^{2}$ Feed conversion ratio (kg feed/kg gain).

Increased DMI in male water buffalo calves fed the higher $\mathrm{NaHCO}_{3}$ levels in diets could be attributed to a higher rumen $\mathrm{pH}$ (Tucker et al., 1991), blood $\mathrm{HCO}_{3}$ and acid-base balance (Sanchez et al., 1994; Shahzad et al., 2008a; b), suggesting an increased rumen buffering capacity in addition to an increased rumen fluid dilution rate (Rogers et al., 1979). Rogers et al. (1982) reported an increased DMI in dairy cows when a high level of $\mathrm{NaHCO}_{3}$ was supplemented. They further stated that, in addition to a buffering effect, $\mathrm{NaHCO}_{3}$ also increased ruminal osmotic pressure and liquid dilution rate. In the rumen $\mathrm{NaHCO}_{3}$ is disassociated into $\mathrm{Na}^{+}$and $\mathrm{HCO}_{3}{ }^{-}$with non-buffering and buffering effects, respectively (Schneider et al., 1986). Erdman (1988) hypothesized that rumen buffering reduces the extent of acidity produced by volatile fatty acid and lactic acid production in the rumen and, therefore, improves the systemic acid-base status. It is also proposed that in the absence of strong buffering effects, propionate decreases feed intake by ruminants through stimulating oxidative metabolism in the liver (Allen, 2000). The decrease in digestibility of nutrients with increasing dietary $\mathrm{NaHCO}_{3}$ levels could be attributed to higher rates of passage of digesta through the digestive tract, leading to reduced rumen retention of nutrients and hence reduced digestibility. A positive correlation between nutrient retention time and digestibility has been documented (Sarwar et al., 1996). However, inconsistent responses have been reported on the effects of $\mathrm{NaHCO}_{3}$ supplementation on nutrient digestibility. A plausible explanation, suggested by Cetinkaya \& Unal (1992), was that differences could be due to differences in feeding regimens, particularly concentrate to forage ratio and level of intake, and types and levels of added mineral buffers.

The higher $\mathrm{N}$ intake and retention were due to increased DMI of the calves fed the 16SB diet. The higher level of $\mathrm{NaHCO}_{3}$ might have prevented systemic acidosis induced by rapid degradation of concentrates and a concomitant drop in ruminal $\mathrm{pH}$. This more desirable $\mathrm{pH}$ for rumen microbes might have increased the post-ruminal supply of amino acids by accelerating rumen microbial multiplication and eventual enhanced $\mathrm{N}$ retention.

A consistent increase in blood $\mathrm{pH}$ with increasing dietary $\mathrm{NaHCO}_{3}$ could be attributed to the gradual increase in dietary $\mathrm{Na}$ content. Sodium is absorbed from the posterior segment of the intestine and the excess in chloride is exchanged for hydrogen ions to sustain electrical neutrality of the body. This activity increases blood $\mathrm{pH}$ and serum bicarbonate concentration by reducing the $\mathrm{H}^{+}$concentration in the blood pool. Similar to the results here, Jackson et al. (2001) reported increased serum bicarbonate levels in dairy calves fed $1.75 \%$ $\mathrm{NaHCO}_{3}$. Waterman et al. (1991) also reported increased blood $\mathrm{H}^{+}$with reduced Na. Furthermore, the phosphate and ammonia buffer system contributes to hydrogen ion excretion. Hydrogen ions combine with phosphate or ammonia after entering the renal tubules and a bicarbonate ion is formed that enters the extracellular fluids to further buffer acids in the extracellular fluids.

The changes in urine $\mathrm{pH}$ noticed in calves fed the 14SB and 16SB diets reflect changes in blood $\mathrm{pH}$, though the kidneys play a vital role in minimizing this change by increasing the urine $\mathrm{pH}$ through the excretion of more $\mathrm{HCO}_{3}{ }^{-}$and the conserving of $\mathrm{H}^{+}$(Roche et al., 2003; Sarwar et al., 2007b; Shahzad et al., 2008a; b). A marked increase in urine $\mathrm{pH}$ had also been reported with increased dietary $\mathrm{Na}$ intake (Waterman et al., 1991). The findings of the present study concur with those of other workers (Jackson et al., 1992; Mosel et al., 1993; Jackson \& Hemken, 1994; Pehrson et al., 1999) who reported increased urine pH with increased dietary $\mathrm{Na}$, and those of Jackson et al. (2001) who noticed increased urine pH (8.09) in dairy 
calves fed a high $\mathrm{Na}$ level in the diet compared to those ( $\mathrm{pH}$ 6.80) fed a low $\mathrm{Na}$ level. The increased urinary $\mathrm{pH}$ in calves fed the $16 \mathrm{SB}$ diet might be attributed to decreased $\mathrm{H}^{+}$and increased $\mathrm{HCO}_{3}{ }^{-}$concentrations (Fredeen et al., 1988). Another possible reason for this could be that urine excretion of serum $\mathrm{HCO}_{3}{ }^{-}$carries with it $\mathrm{Na}^{+}$or other cations for renal rectification of alkalosis (Guyton \& Hall, 2000). Increased urine $\mathrm{pH}$ was shown to be an indicator of blood $\mathrm{pH}$ and $\mathrm{HCO}_{3}{ }^{-}$as it reliably reflected that the acid load of lactating cows decreased dramatically when $\mathrm{NaHCO}_{3}$ concentration, particularly the sodium content, increased in the diet (Hu \& Murphy, 2004). Moreover, male water buffalo calves fed the 16SB diet tended to have a high blood pH due to more $\mathrm{HCO}_{3}{ }^{-}$production and $\mathrm{H}^{+}$excretion (Tucker et al., 1992).

The higher serum $\mathrm{Na}^{+}$content was primarily due to the higher dietary concentration of this mineral which significantly altered the serum cation-anion balance. A slight metabolic acidosis in cows induced by low sodium dietary content has been reported to enhance $\mathrm{Ca}$ absorption from the alimentary tract (Lomba et al., 1978) or increase Ca mobilization from bones (Joyce et al., 1997). This is also supported by Block (1994) who attributed increased serum Ca to increased Ca supply, derived directly from Ca mobilization from bones and indirectly through increased absorption from the intestine due to increased synthesis of 1,25-dihydrocycholecalciferol (hormonally active form of vitamin $\mathrm{D}_{3}$ ) in response to metabolic acidosis. This is also supported by Gaynor et al. (1987) who observed higher plasma hydroxyproline, an index of bone resorption, in cows experiencing metabolic acidosis. Increased plasma $\mathrm{Ca}$ in sheep with a low blood $\mathrm{pH}$ has been reported by Espino et al. (2003). A slight decreasing trend in serum S with increased DCAD level might be due to dietary S concentration. Moreover, S balance is regulated renally and not intestinally, thus increased intakes will increase blood serum S (Krijgsheld et al., 1979). These findings are consistent with those of Delaquis \& Block (1995).

The increased weight gain of the male water buffalo calves fed the16SB diet was due to an increased DMI. The plausible explanation of the higher weight gain because of higher feed consumption by the buffalo calves fed diets with gradual increasing dietary SB levels could be attributed to its favourable effects on ruminal $\mathrm{pH}$, rumen microbial activity, fermentation and passage rate from the rumen, resulting in higher nutrient consumption. It is also stated that metabolic activities in growing animals take place at a rapid rate, leading to higher production of $\mathrm{CO}_{2}$ in the cell. When production of $\mathrm{CO}_{2}$ increases when it is exhaled, the enhanced $\mathrm{CO}_{2}$ production makes the cellular environment acidic (Robert et al., 2004) as $\mathrm{CO}_{2}$ acts as an acid (carbonic acid) after combining with water (Guyton \& Hall, 2000). This slight acidic situation restricts the cell and its organelles to work optimally and consequently reduced cellular activities, resulting in poor growth rate. The activity of this phenomenon might have operated in calves fed OSB diet. The alkalogenic nature of the high SB diet might have allowed a cell to work to its optimal potential by sustaining the cellular environment slightly alkaline through counteracting the cellular acidity produced by $\mathrm{CO}_{2}$. Similar findings were reported by Jackson et al. (1992) who recorded a quadratic increase in the average daily gain in growing calves when bicarbonate salts of $\mathrm{Na}$ or $\mathrm{K}$ were supplemented in diets. It is suggested that the lower growth rate in the calves fed the OSB diet was due to low DMI because of metabolic acidosis induced by low dietary Na. Moreover, when the acid balance of the diet is towards acidosis, apart from the homeostatic welfare, most metabolic pathways cannot work under optimal conditions and are more involved in homeostatic regulation than growth.

The findings of the present study suggest that inclusion of $1.2 \% \mathrm{NaHCO}_{3}$ in the concentrate diets of growing male water buffalo calves increased their feed intake, $\mathrm{N}$ balance and weight gain. However, further studies aimed at examining the influence of altering $\mathrm{NaHCO}_{3}$ levels on rumen ecology and digestion kinetics are warranted in order to get a better understanding of $\mathrm{NaHCO}_{3}$ supplementation in buffaloes.

\section{References}

AOAC, 2003. Official Methods of Analysis. (15th ed.). Association of Official Analytical Chemists, Arlington, Virginia, USA.

Belibasakis, N.G. \& Triantosa, A., 1991. Effects of sodium carbonate on milk yield, milk composition, and blood components of dairy cows in early lactation. J. Dairy Sci. 74, 467-472.

Block, E., 1994. Manipulation of dietary cation-anion difference on nutritionally related production diseases, productivity, and metabolic responses of dairy cows. J. Dairy Sci. 77, 1437-1450.

Cetinkaya, N. \& Unal, S., 1992. Effects of bicarbonate on rumen degradability of concentrate and grass hay in Angora goats. Small Rumin. Res. 9, 17-123. 
Challa, A., Krieg, J.R., Thabet, M.A., Veldhuis, J.D. \& Chan, J.C.M., 1993. Metabolic acidosis inhibits growth hormones secretion in rats: mechanism of growth retardation. Am. J. Physiol. 65, 547-553.

Delaquis, A.M. \& Block, E., 1995. Acid-base status, renal function, and macromineral metabolism of dry cows fed diets differing in cation-anion difference. J. Dairy Sci. 78, 604-619.

Erdman, R.A., 1988. Dietary buffering requirements of lactating dairy cow: A review. J. Dairy Sci. 71, 3246-3252.

Espino, L., Guerrero, F., Suarez, M.L., Santamarina, G., Goico, A. \& Fidalgo, L.E., 2003. Long term effects of dietary cation anion difference on acid base status and bone morphology in reproducing ewes. J. Vet. Med. 50, 488-495.

Fredeen, A.H., DePeters, E.J. \& Baldwin, R.L., 1988. Characterization of acid-base disturbances and effects on calcium and phosphorus balances of dietary fixed ions in pregnant or lactating does. J. Anim. Sci. 66, 159-165.

Gaynor, P.J., Mueller, F.J., Miller, J.K., Ramsey, N., Goff, J.P. \& Horst, R.L., 1987. Parturient hypocalcemia in Jersey cows fed alfafa haylage based diets with different cation to anion rations. J. Dairy Sci. 72, 2525-2531.

Goering, H.G. \& Van Soest, P.J., 1970. Forage Fiber Analysis. Agricultural Handbook, vol. 379. UPSDA, USA.

Guyton, A.C. 1976. Textbook of Medical Physiology. (5th ed.). Philadelphia: W.B. Saunders Company, P.A., USA.

Guyton, A.C., 1991. Textbook of Medical Physiology. (8th ed.). Philadelphia: W.B. Saunders Company, P.A., USA.

Guyton, A.C. \& Hall, J.E., 2000. Textbook of Medical Physiology. (10th ed.). Philadelphia: W.B. Saunders Company, P.A., USA.

Harold, V., 1976. Practical Clinical Biochemistry. (4th ed.). Arnold-Heinemann Publisher (Pvt.) New Delhi, India.

Hu, W. \& Murphy, M.R., 2004. Dietary cation-anion difference effects on performance and acid-base status of lactating dairy cows: A meta-analysis. J. Dairy Sci. 87, 2222-2229.

Jackson, J.A. \& Hemken, R.W., 1994. Calcium and cation-anion difference effects on feed intake, body weight gain, and humoral response of dairy calves. J. Dairy Sci. 77, 1430-1436.

Jackson, J.A., Akay, V., Franklin, S.T. \& Aaron, D.K., 2001. The effect of cation-anion difference on calcium requirement, feed intake, body weight gain, and blood gasses and mineral concentrations of dairy calves. J. Dairy Sci. 84, 147-153.

Jackson, J.A., Hopkins, D.M., Xin, Z. \& Hemken, R.W., 1992. Influence of cation-anion balance on feed intake, body weight gain, and humoral response of dairy calves. J. Dairy Sci. 75, 1281-1286.

Javaid, A., Nisa, M., Sarwar, M. \& Shahzad, M.A., 2008. Ruminal characteristics, blood pH, blood urea nitrogen and nitrogen balance in buffalo (Bubalus bubalis) bulls fed diets containing various level of ruminally degradable protein. Asian-Aust. J. Anim. Sci. 21, 51-58.

Joyce, P.W., Sanchez, W.K. \& Goff, J.P., 1997. Effect of anionic salts in prepartum diets based on alfalfa. J. Dairy Sci. 80, 2866-2875.

Krijgsheld, K.R., Frankena, H., Scholtens, E., Zweens, J. \& Mulder, G.J., 1979. Absorption, serum levels and urinary excretion of inorganic sulfate after oral administration of sodium sulfate in the conscious rat. Biochem. Biophy. Act. 586, 492-499.

Lomba, F., Chauvaux, G., Teller, E., Lengele, L. \& Benefit, V., 1978. Calcium digestibility in cows as influenced by the excess of alkaline ions over stable acid ions in their diets. Br. J. Nutr. 39, 425-431.

Mandebvu, N. \& Galbraith, H., 1999. Effect of sodium bicarbonate supplementation and variation in the proportion of barley and sugar beet pulp on growth performance and rumen, blood and carcass characteristics of young entire male lambs. Anim. Feed Sci. Technol. 82, 37-49.

Mosel, V., Klooster, V., Mosel, V. \& Kuilen, J.V., 1993. Effects of reducing dietary [( $\left.\left.\mathrm{Na}^{+} \mathrm{K}^{+}\right)-\left(\mathrm{Cl}^{-}+\mathrm{SO}_{4}\right)\right]$ on the rate of calcium mobilisation by dairy cows at parturition. Res. Vet. Sci. 54, 1-9.

Owens, F.N., Secrist, D.S., Hill, W.J. \& Gill, D.R., 1998. Acidosis in cattle: A review. J. Anim. Sci. 76, 275-286.

Pehrson, B., Svensson, C., Gruvaeus, I. \& Virkki, M., 1999. The influence of acidic diets on the acid-base balance of dry cows and the effect of fertilization on the mineral content of grass. J. Dairy Sci. 82, $1310-1316$. 
Robert, W., Putnam, J., Filosa, A. \& Ritucci, A., 2004. Cellular mechanisms involved in $\mathrm{CO}_{2}$ and acid signalling in chemosensitive neurons. Am. J. Physiol. Cell Physiol. 287, 1493-1526.

Robertson, J.A., 1987. Metabolic and hormonal responses to neuroleptanalegesia (etorphine and acepromazine) in the horse. Equine Vet. J. 19, 214-217.

Roche, J.R., Dalley, D., Moate, P., Grainger, C., Rath, M. \& Mara, F.O., 2003. Dietary cation anion difference and the health and production of pasture-fed dairy cows. 2. Non-lactating prepartum cows. J. Dairy Sci. 86, 979-986.

Rogers, J.A., Davis, C.L. \& Clark, J.C., 1979. Alteration or rumen fermentation in steers by increasing rumen fluid dilution rate with mineral salts. J. Dairy Sci. 62, 1599-1607.

Rogers, J.A, Davis, C.L. \& Clark, J.C., 1982. Alteration or rumen fermentation milk fat synthesis and nutrient utilization with mineral salts in dairy cattle. J. Dairy Sci. 65, 577-582.

Russell, J.B., Connor, J.D.O., Fox, D.G., Van Soest, J.P. \& Sniffen, C.J., 1992. A net carbohydrate and protein system for evaluating cattle diets. I. Ruminal fermentation. J. Anim. Sci. 70, 3551-3557.

SAS, 1988. Statistical Analysis System. SAS user's guide: Statistics, SAS Inst. Inc., Carry, N.C., USA.

Sanchez, W.K., McGuire, M.A. \& Beede, D.K., 1994. Macromineral nutrition by heat stress interactions in dairy cows: Review and original research. J. Dairy Sci. 77, 2051-2079.

Sanchez, W.K., Beede, D.K. \& Cornell, J.A., 1997. Dietary mixtures of sodium bicarbonate, sodium chloride, and potassium chloride: Effects on lactational performance acid-base status, and mineral metabolism of Holstein cows. J. Dairy Sci. 80, 1207-1216.

Sarwar, M., Firkins, J.K. \& Estridge, M.L., 1992.Effects of varying forages and concentrates carbohydrates on nutrients digestibilities and milk production by dairy cows. J. Dairy Sci. 75, 1533-1539.

Sarwar, M., Firkins, J.L. \& Estridge, M.L., 1996. Effects of varying forage and concentrate carbohydrates on nutrients digestibilities and milk production by dairy cows. J. Dairy Sci. 75, 1540-1542.

Sarwar, M., Khan, M.A., Nisa, M. \& Iqbal, Z., 2002a. Dairy industry in Pakistan: A Scenario. Int. J. Agric. Biol. 3, 420.

Sarwar, M., Khan, M.A. \& Iqbal, Z., 2002b. Feed resources for livestock in Pakistan. Status Paper. Int. J. Agric. Biol. 4, 186-192.

Sarwar, M., Shahzad, M.A. \& Nisa, M., 2007a. Influence of varying level of sodium bicarbonate on milk yield and its composition in early lactating Nili Ravi buffaloes. Asian-Aust. J. Anim. Sci. 20, 1858-1864.

Sarwar, M., Shahzad, M.A. \& Nisa, M., 2007b. Nutrients intake, acid base status and growth performance of growing thalli lambs fed varying level of dietary cation anion difference. Asian-Aust. J. Anim. Sci. 20, 1713-1720.

Schneider, P.L., Beede, D.K. \& Wilcox, C.J., 1986. Responses of lactating cows to dietary sodium source and quantity and potassium quantity during heat stress. J. Dairy Sci. 69, 99-110.

Shahzad, M.A., Sarwar, M. \& Nisa, M., 2007. Nutrient intake, acid base status and growth performance of growing buffalo male calves fed varying level of dietary cation anion difference. Livest. Sci. 111, 136-143.

Shahzad, M.A., Sarwar, M. \& Nisa, M., 2008a. Influence of altering dietary cation anion difference on milk yield and its composition of early lactating Nili Ravi buffaloes in summer. Livest. Sci. 113, 133-143.

Shahzad, M.A., Sarwar, M. \& Nisa, M., 2008b. Influence of varying dietary cation anion difference on serum minerals, mineral balance and hypocalcemia in Nili Ravi buffaloes. Livest. Sci. 113, 52-61.

Shahzad, M.A., Sarwar, M., Nisa, M., Iqbal, A. \& Riaz, M., 2009a. Feed consumption and weight gain of growing buffalo calves as influenced by feeding fermentable energy source in corncobs based diet. Pakistan J. Zool. 9, 707-710.

Shahzad, M.A., Sarwar, M., Aqile, A., Nisa, M., Mahmood, K. \& Khan, M.S., 2009b. Impact of stage of maize fodder harvest on chemical composition, nutrient digestibilities and nitrogen balance in buffalo bulls. Pakistan J. Zool. 9, 717-720.

Spanghero, M., 2004. Prediction of urinary and blood pH in non-lactating dairy cows fed anionic diets. Anim. Feed Sci. Technol. 116, 83-92.

Steel, R.G.D. \& Torrie, J.H., 1984. Principles and Procedures of Statistics. A Biometrical Approach. $2^{\text {nd }}$ ed. McGraw Hill Book Co. Inc., New York, USA.

Tucker, W.B., Xin, B.Z. \& Henken, R.W., 1991. Influence of calcium chloride on systemic acid-base status and calcium metabolism in dairy heifers. J. Dairy Sci. 74, 1401-1411. 
Tucker, W.B., Hogue, J.F., Waterman, D.F., Swenson, T.S., Xin, Z., Hemken, R.W. Jackson, J.A., Adams, J.D. \& Spicer, L., 1992. Sulfur should be included when calculating the dietary cation-anion balance of diets for lactating dairy cows. Anim. Reprod. Sci. Oklahoma Res. Stat., Oklahoma City, OK. pp. 141-150.

Van Soest, P.J., Robertson, H.B. \& Lewis, B.A., 1991. Methods of dietary fiber, NDF and non-starch polysaccharides in relation to animal material. J. Dairy Sci. 74, 3583-3597.

Waterman, D.F., Swenson, S.A., Tucker, W.B. \& Henkin, R.T., 1991. Role of magnesium in the dietary cation-anion balance equation for ruminants. J. Dairy Sci. 74, 1866-1873.

West, J.W., Mullinix, B.J. \& Sandifer, T.G., 1991. Changing dietary electrolyte balance for dairy cows in cool and hot environments. J. Dairy Sci. 74, 1662-1669. 